\title{
Optimization of bistable viscoelastic systems
}

\author{
Jensen, Kristian Ejlebjærg; Szabo, Peter; Okkels, Fridolin
}

Published in:

Proceedings of the 10th World Congress on Structural and Multidisciplinary Optimization

Publication date:

2013

Link back to DTU Orbit

Citation (APA):

Jensen, K. E., Szabo, P., \& Okkels, F. (2013). Optimization of bistable viscoelastic systems. In Proceedings of the 10th World Congress on Structural and Multidisciplinary Optimization

\section{General rights}

Copyright and moral rights for the publications made accessible in the public portal are retained by the authors and/or other copyright owners and it is a condition of accessing publications that users recognise and abide by the legal requirements associated with these rights.

- Users may download and print one copy of any publication from the public portal for the purpose of private study or research.

- You may not further distribute the material or use it for any profit-making activity or commercial gain

- You may freely distribute the URL identifying the publication in the public portal

If you believe that this document breaches copyright please contact us providing details, and we will remove access to the work immediately and investigate your claim 


\title{
OPTIMIZATION OF BISTABLE VISCOELASTIC SYSTEMS
}

\author{
$\underline{\text { Kristian E. Jensen }}^{1}$, Peter Szabo ${ }^{2}$, Fridolin Okkels ${ }^{3}$ \\ ${ }^{1}$ Technical University of Denmark, Copenhagen, Denmark, kristian.jensen@nanotech.dtu.dk \\ ${ }^{2}$ Technical University of Denmark, Copenhagen, Denmark, ps@kt.dtu.dk \\ ${ }^{3}$ Technical University of Denmark, Copenhagen, Denmark, fridolin.okkels@nanotech.dtu.dk
}

\begin{abstract}
Viscoelastic fluids appear in many industrial applications, e.g. food and plastic processing due to the presence of biological cells and synthetic polymers, respectively. It is the elastic character of these small constituents that give rise to exceptional fluid properties. Within modeling this elastic behavior is often described by a statistical ensemble of flexible dumbbells (that is two point masses connected by a spring) in what is collectively referred to as differential constitutive equations.

We consider the flow of a viscoelastic flow in a symmetric cross geometry. For small driving pressures the flow is symmetric, but beyond a certain critical pressure the symmetric flow becomes unstable; two stable asymmetric solutions appear, and forcing of the unstable symmetric flow beyond the critical pressure gives rise to increased resistance.

We have combined a state-of-the-art model for viscoelastic flow with topology optimization [1] in a high level finite element package (COMSOL) [2]. We use this framework on the cross geometry with the aim to reduce the critical driving pressure corresponding to the point of bistability. This quantity is, however, not explicitly contained in the solution, so we opt for a heuristic approach based on the dissipation ratio between the asymmetric and unstable symmetric flow solutions. We find a solution that reduces the driving pressure required for bistability, and furthermore is in agreement with the ideas of experimental researchers [3].

Previously we have used this combination to find a novel material layout for a viscoelastic rectifier [1] and verified the performance experimentally [4].
\end{abstract}

[1] K.E, Jensen et al., Topology optimization of viscoelastic rectifiers, Appl. Phys. Lett. 100(23), 234102, 2012.

[2] L.H. Olesen, et al., A high-level programming-language implementation of topology optimization applied to steady-state Navier-Stokes flow, International Journal for Numerical Methods in Engineering, 65(7):975-1001, 2006.

[3] A. Groisman, et al., Microfluidic Memory and Control Devices, Science, 300(5621):955, 2003.

[4] K.E, Jensen et al., Experimental characterisation of a novel viscoelastic rectifier design, Biomicrofluidics 6, 044112, 2012. 